\title{
Professional practice of dietitians in the Brazilian School Feeding Program: A multiple case study
}

\author{
Atuação do nutricionista no Programa \\ Nacional de Alimentação escolar: \\ estudo de casos múltiplos
}

Patrícia Fernanda Ferreira PIRES ${ }^{1}$

Anabelle RETONDARIO²

Claudia Choma Bettega ALMEIDA ${ }^{3}$

Suely Teresinha SCHMIDT ${ }^{3}$

Marcia Regina BEUX ${ }^{4}$

Sila Mary Rodrigues FERREIRA ${ }^{4}$

\section{A B S T R A C T}

\section{Objective}

To assess dietician's numerical parameters for school feeding and discuss limitations and possibilities for professional practice in the municipalities of Vale do Ivaí, in Northern Paraná, Brazil.

\section{Methods}

This is a multiple case study. A semi-structured interview was administered to dietitians working at the School Feeding Program in nine cities located in Vale do Ivaí, Paraná, Brazil. Resolution n 465/2010, from the Brazilian Federal Board of Dietitians, was used to calculate the adequacy of working hours of dietitians. The legistation of the Brazilian School Feeding Program was applied to discuss professional practice.

1 Universidade de São Paulo, Faculdade de Saúde Pública, Programa de Pós-Graduação em Nutrição e Saúde Pública. São Paulo, SP, Brasil.

2 Universidade Federal de Santa Catarina, Centro de Ciências da Saúde, Programa de Pós-Graduação em Nutrição. Florianópolis, SC, Brasil.

3 Universidade Federal do Paraná, Programa de Pós-Graduação em Alimentação e Nutrição, Departamento de Nutrição. Curitiba, PR, Brasil.

${ }^{4}$ Universidade Federal do Paraná, Programa de Pós-Graduação em Alimentação e Nutrição, Departamento de Patologia Básica. Av. Prefeito Lothário Meissner, 632, Jd. Botânico, 80210-170, Curitiba, PR, Brasil. Correspondência para/C orrespondence to: SMR FERREIRA. E-mail: <sila.ufpr@gmail.com>.

Article based on the master's thesis of PFF PIRES, intitled "Qualidade do feijão (Phaseolus vulgaris L.), classe cores, proveniente da agricultura familiar e do mercado varejista destinado à alimentação escolar". Universidade Federal do Paraná; 2014.

Support: Conselho Nacional de Desenvolvimento Cientifico e Tecnológico (Process n 552448/2011-7). 


\section{Results}

All the cities had at least one dietitian responsible for the School Feeding Program. The percentage of adequate working hours was from 20 to $66 \%$. Some dietitians were involved in management activities, administration, procurement, and accounting, in addition to dietitian assignments for the School Feeding Program. Most dietitians worked in other sectors of the municipalities such as the health system, social assistance, and at events. This practice could compromise compliance of technical activities that must be met by the dietitians of the School Feeding Program.

\section{Conclusion}

The number of dietitians in most of cities working at School Feeding Program is not sufficient to meet the number of students. The insuficient workload and excessive activities could hinder the development of dietitian's private activities. The hiring of nutrition and dietitian technicians and administrative assistants for bureaucratic activies is recommended.

Keywords: Dietitians. Legislation. Professional practice. School feeding.

\section{RE S U M O}

\section{Objetivo}

Verificar a adequação dos parâmetros numéricos de nutricionistas na alimentação escolar e discutir limites e possibilidades da atuação profissional no Programa de Alimentação Escolar em municípios do Vale do Ivaí, Norte do Paraná.

\section{Métodos}

Estudo de casos múltiplos realizado por meio de entrevista semiestruturada com nutricionistas da alimentação escolar de nove municípios do Vale do Ivaí. A Resolução n 465/2010, do Conselho Federal de Nutricionistas, foi utilizada como base para cálculo da adequação da carga horária do nutricionista. A legislação do Programa Nacional de Alimentação Escolar foi utilizada para discussão da atuação profissional.

\section{Resultados}

Os municípios contavam com nutricionista responsável técnico pelo Programa de Alimentação Escolar, porém, o percentual de adequação da carga horária variou de 20 a 66\%. Foram evidenciadas atividades de gestão, licitação e contabilidade, além das atribuições do nutricionista previstas para o Programa. A maioria dos nutricionistas também atendia a outras áreas dos municípios, como saúde, social e eventos, o que sugere um comprometimento das atribuições do profissional e, consequentemente, da execução do Programa.

\section{Conclusão}

O número de nutricionistas no Programa Nacional de Alimentação Escolar nos municípios investigados é insuficiente em relação ao número de alunos. A carga horária insuficiente e a demanda excessiva de atividades podem impedir que o desenvolvimento de atividades privativas do nutricionista. A contratação de técnicos em nutrição e dietética e auxiliares administrativos para tarefas burocráticas deve ser incitada.

Palavra-chave: Nutricionistas. Legislação como assunto. Prática profissional. Alimentação escolar.

\section{INTRODUCTION}

The Brazilian government has provided the Programa Nacional de Alimentação Escolar (PNAE, National School Feeding Program) for over 70 years and it is the largest and oldest School Feeding Program in the world [1]. In 2015, the Program benefited more than 42 million students, with an investment of approximately $\mathrm{R} \$ 3.8$ billion [2]. Brazil is 2 nd in the international ranking among countries that provide school feeding to children. In addition to other public policies, the PNAE contributes to the promotion of Food and Nutrition Safety (FNS) of schoolchildren through the provision of healthy food and activities for Food and Nutrition Education (FNE) [1,3].

The inclusion of the dietitian in the PNAE occurred in 1994 after Law $n^{\circ}$ 8,913/1994 [4] 
was implemented. However, it was only after the publication of Resolution $n^{\circ} 32 / 2006$ [5] that the technical responsibility of the dietitian was defined within the Program $[6,7]$.

Throughout its history, the PNAE has presented advances in implementation strategies. Within the legal framework in force (Law $n^{\circ}$ 11.947/2009 and Resolution $n^{\circ}$ 26/2013) [3,8] the activities for food and nutrition and FNS were established to be performed by a skilled dietitian and hired by the Implementation Agencies (IAg).

The implementation agencies are the municipal city halls, which must offer adequate working conditions for the dietitian and comply with the specified minimum number of professionals per schoolchild, according to Resolution $n^{\circ} 465 / 2010$ [9] of the Federal Board of Dietitians [3]. Although the resolutions are purely normative administrative acts, without the force of law (principle of legality) [10], this Resolution [3] was proposed by experient professionals in the subject and is in agreeement with similar legislations from other countries when it regulates, for example, the acquisition of local agricultural produce, involvement of school community agents in program decisions, and decentralized management [11]. Thus, the resolution must be respected when planning and implementing School Feeding Programs (SFP) in Brazil to ensure healthy eating and promote health in schools.

The dietitian associated with PNAE must perform technical duties [7-9] to achieve the objectives of the Program and assist the promotion of FNS in the school environment. Although it is important that studies identify the profile of the dietitian of SFP and the characteristics of professional training [7,12-14], a gap has been identified regarding research on the adequate number of dietitians and its implications on the Program. Therefore, the objective of the present study was to verify the adequate number of dietitians in SFP and to identify and discuss limitations and possibilities of professional performance in PNAE in the territory of Vale do Ivaí, Paraná, Brazil.

\section{METHODS}

This cross-sectional descriptive multiple case study [15] was conducted from August to September 2013 through interviews with dietitians from nine IAg in the territory of Vale do Ivaí. This region consists of 25 municipalities in the North of the State of Paraná, with about 309,000 inhabitants, representing $3 \%$ of the state's population [16]. The agricultural activity in the region is predominantly from family farming, of which $58 \%$ of the productive farms depend on domestic labor [16].

The study was carried out simultaneously with a master's research, in which the main inclusion criterion was that the municipalities received beans from. Only nine of the 25 municipalities (36\%) met the inclusion criterion and were selected for study, coded as: IAg1, IAg2, IAg3, IAg4, IAg5, IAg6, IAg7, IAg8 and IAg9. Among these municipalities, only |Ag1 was considered medium-sized, with more than 100 thousand inhabitants, and the Municipal Human Development Index (M-HDI) is above the state average. The others were small, with less than 50,000 inhabitants, and the M-HDI was below the state average $[17,18]$.

The implementation agencies involved in this research consisted of establishments of the municipal school system with early childhood education and first years of elementary education. The number of enrolled students was obtained from the 2013 School Census [19].

An interview was administered by one of the researchers, a dietitian, to identify the following information: number of professionals working at the PNAE, working hours, time of service to IAg, activities developed at the SFP and other areas of IAg, perception related to the quality of the SFP after inclusion of family farming products, operationalization of technical practice, and main difficulties found in the occupation.

The number of professionals in each IAg was reported by the dietitians. The workload 
was collected in weekly hours. When more than one dietitian attended the same IAg, the total workload was obtained by the sum of the hours of the professionals working for the municipality.

To analyze the number of professionals and the minimum technical workload required for each $\mathrm{IAg}$, the minimum parameters set forth in Federal Board of Dietian Resolution $n^{\circ} 4.65 / 2010$ [9] were used, which establishes the minimum number of responsible dietitians and technical staff, according to the number of students.

To calculate the workload adequacy, the percentage of work to the total recommended minimum working hours [9] was used and compared to the total workload of the professionals:

workload adequacy $=\frac{\text { total workload of profissionals } \times 100}{\text { total recommended minimum working hours }}$

The service time at the IAg was collected in years and months and presented as mean and minimum and maximum values.

The activities developed at the IAg, designation of tasks, and perception regarding the food supply from family farming to the PNAE were investigated using a semi-structured interview containing pre-defined but flexible questions, allowing the researcher to investigate other issues that arose during the interview [20].
The activities developed by the professionals, such as the training of family farmers, activities in other areas of the IAg, implementation of bureaucratic activities at the PNAE and assistance in the activities of the School Feeding Board (SFB), were investigated in the semistructured interview (whether or not they carry out the activity). When the dietitian reported developing activities in other areas of the $I \mathrm{Ag}$, the researcher inquired about the areas.

Regarding the perception of changes in PNAE, when supplied with family farming produce, the dietitians were asked if they perceived any differences in quality (perceived or non-perceived). Thefollowing question was related to the reason for this perception. In addition, 27 items were presented to the dietitians regarding which produce they considered to be the best, the one from the family farming produce or retail market (Chart 1).

The designation of duties of the nutritionist and the difficulties encountered were approached based on the items foreseen in Federal Board of Dietitians Resolution [9], allowing the interviewee to further discuss the topic, if desired.

The project was approved by the Research Ethics Committee for Human Studies of the Department of Health Sciences of the Universidade Federal do Paraná and the Municipal Secretary of Education of the participating IAg,

Chart 1. Aspects investigated about the perception of dietitians comparing the quality of produce from family farming and the retail market.

\begin{tabular}{lll}
\hline Nutritional value & Price & Health benefit \\
Health risk & Diversity/variety & General appearance \\
Source & Ease of purchase & Degradation of the environment \\
Social promotion & Agrochemical residues & Microbiological contamination \\
Sustainability & Form of production & Economic development \\
Presence of impurities & Presence of insects & Cooking of grains \\
Packing/packaging & Standardization & Perishability/durability \\
Sensory aspects (color, texture, aroma and taste) & Capacity to meet demand & Respect for regional eating habits \\
Care related to the standard identity of quality & Contact, relationship and trust with Nutrition and food safety & of \\
& the supplier & schoolchildren
\end{tabular}


under registration $n^{\circ}$ 11460612.8.0000.0102. The participants involved in the study agreed and signed the Informed Consent Form. Confidentiality and anonymity of the interviewees were guaranteed.

\section{RES U L T S}

Nine dietitians working at the PNAE in nine municipalities of Vale do Ivaí participated in the study. In the municipality IAg1, two dietitians from the PNAE (responsible dietitians and technical staff) were interviewed. The same nutritionist worked in the municipalities IAg7 and IAg9, dedicating 20 hours a week to each one. The number of students and the adequacy of the number of dietitians are shown in Table 1.

Regarding the number of dietitians, the average adequate number among the municipalities was $37 \%$. The lowest percentages were found mainly in IAg with more than 300 students attending early childhood education, a type of school that requires a greater number of professionals. The deficit of dietitians ranged from 1 to 11 professionals. IAg2 presented the highest percentage of adequate number of dietitians (66\%) and the lowest workload deficit (20 hours per week). IAg1 presented the lowest percentage of adequacy (20\%) and the highest workload deficit (310 hours per week).

The characterization of the professionals regarding the activities developed at the PNAE is shown in Table 2.

The nine implementation agencies depended on a responsible dietitian from the PNAE. The average time of service provided by dietitians was 4 years and the workload ranged from 20 to 40 hours per week.

Most implementation agencies $(n=5)$ had a responsible dietitian and a coordinator on the PNAE team. Half of the dietitians reported working in other areas of the $\mathrm{IAg}$ and participated in the training of family farmers. All professionals reported performing bureaucratic activities at the PNAE, assisting the SFB, and they believed that the acquisition of family farming produce results in improvements to the IAg.

When investigating the activities developed by the professionals, it was found that the activities directly related to the acquisition of food, supply availability of the School Feeding Program, and hygienic-sanitary conditions were considered a priority. According to the report of the dietitian from IAg2, the highest workload is dedicated to these tasks. All dietitians reported performing activities that were not foreseen as part of their duties.

\section{DISCUSSION}

The aim of the study was to verify the adequate number of dietitians on the SFP and discuss the limitations and possibilities for professional practice at the PNAE in Vale do Ivaí. Although all IAg have responsible dietitians, none met the minimum number of dietitians for the number of students, as foreseen in the regulation. In addition to the lack of professionals, all dietitians reported having bureaucratic activities and, half of them, working in other areas of the IAg.

The fact that all IAg have a responsible nutritionist is due to the obligation imposed by Resolution no 32/2006 [5]. However, only IAg1, with the largest number of students $(10,078)$, had two dietitians on the team, which is still insufficient to meet the parameters established by the Resolution [9].

Since the implementation of Resolution $n^{\circ} 32 / 2006$ [5], the presence of responsible dietitians at PNAE has been increasing. Between 2003-2011, the percentage of Brazilian municipalities with dietitians increased from 12\% to $79 \%$ [7]. However, there are discrepancies among the different regions of the country. While in the North $59 \%$ of municipalities have dietitians, in the South this percentage was $85 \%$ [7]. Therefore, it is pertinent that research 


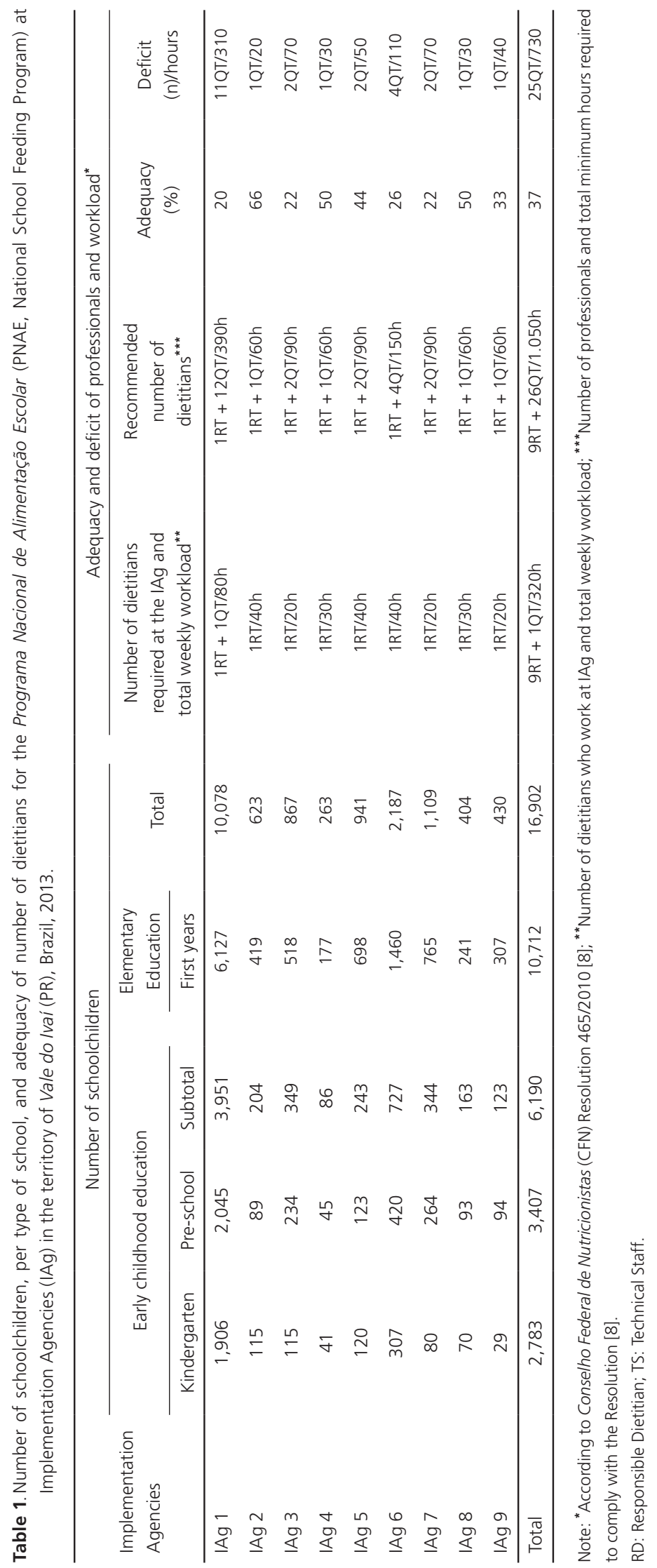


Table 2. Characteristics of the responsible dietitian and technical staff for school feeding in the territory of Vale do Ivaí (PR), Brazil, 2013.

\begin{tabular}{|c|c|c|}
\hline \multirow{3}{*}{$\begin{array}{l}\text { Characteristics } \\
\text { Working time of the responsible dietitian with school food (years) } \\
\text { Characteristics }\end{array}$} & \multicolumn{2}{|c|}{ Mean (minimum to maximum) } \\
\hline & \multicolumn{2}{|c|}{4 years $(0.5$ to 9$)$} \\
\hline & $\mathrm{n}$ & $\%$ \\
\hline \multicolumn{3}{|l|}{ Workload at the PNAE $(n=10)$} \\
\hline 20 hours per week & 3 & 30 \\
\hline 30 hours per week & 2 & 20 \\
\hline 40 hours per week & 5 & 50 \\
\hline \multicolumn{3}{|l|}{ Work team at the PNAE at the IAg $(n=9)$} \\
\hline Only one responsible dietitian & 3 & 33 \\
\hline One responsible dietitian + one coordinator & 5 & 56 \\
\hline One responsible dietitian + one TS + one coordinator & 1 & 11 \\
\hline \multicolumn{3}{|l|}{ Works in other areas of the IAg $(n=10)$} \\
\hline Yes & 5 & 50 \\
\hline No & 5 & 50 \\
\hline \multicolumn{3}{|l|}{ Performs bureaucratic activities at the PNAE $(n=10)$} \\
\hline Yes & 10 & 100 \\
\hline No & 0 & 0 \\
\hline \multicolumn{3}{|l|}{ Performs or assists training of family farmers $(n=10)$} \\
\hline Yes & 5 & 50 \\
\hline No & 5 & 50 \\
\hline \multicolumn{3}{|c|}{ Believes that the acquisition of family farmers produce improves the PNAE $(n=10)$} \\
\hline Yes & 10 & 100 \\
\hline 1) Improves the nutritional value of school food & 10 & 100 \\
\hline 2) Respects the local eating habits & 9 & 90 \\
\hline 3) Brings health benefits & 9 & 90 \\
\hline 4) Promotes food and nutritional safety of schoolchildren & 6 & 60 \\
\hline No & 0 & 0 \\
\hline \multicolumn{3}{|l|}{ Assists activities of the School Feeding Board $(n=10)$} \\
\hline Yes & 10 & 100 \\
\hline No & 0 & 0 \\
\hline
\end{tabular}

Note: The "Work Team" characteristics refers to the Implementation Agencies (IAg) and, therefore, there are 9 answers. The other characteristics refer to the responsible dietitians and Technical Staff (TS) and, therefore, there are 10 answers. The responsible dietitian for IAg7 and IAg9 answered an interview for each IAg.

PNAE: Programa Nacional de Alimentação Escolar (National School Feeding Program).

be conducted to diagnose the adequacy in all regions of the country.

The interviewed dietitians use their total workload according to the demand for service in the areas of IAg. Although they agree that the highest workload is dedicated to the PNAE, the percentage adequacy found in the present research may be even lower in practice. This is because the adequacy calculation took into consideration work contracts, since the professionals had difficulties reporting the exact time dedicated to the PNAE.

Failure to comply with the proposed parameters [9] makes it difficult to carry out the technical assignments due to bureaucratic and administrative activities that other professionals could perform. Furthermore, the Program's guidelines specify that the IAg must provide adequate working conditions and comply with the minimum reference parameters $[3,8]$. 
Of the implementation agencies surveyed, the workload of the dietitian was 30 hours per week or more in $66 \%$ of the IAg. Considering that the current resolution [9] establishes that a minimum of 30 hours per week must be fulfilled by the dietitian at the SFP, 33\% of the IAg were in disagreement [9]. The lack of standardization of the workload at the PNAE can be due to the lack of knowledge of the Resolution [9]. A new law or an adjustment to Law $n^{\circ} 11.947 / 2009$ [3] establishing the working hours of dietitians could remedy this problem. This action is required since the resolutions of the boards do not have force of Law and, therefore, do not have to be obligatorily met.

In half of the IAg, the workload of the dietitian was distributed between the activities at the PNAE and other areas of the city hall, mainly in health, social activities and events. This situation has also been discussed in the literature $[12,13]$ and can cause work overload. According to some interviewees, the need to meet other demands of the municipality reduces the time devoted to the PNAE and, consequently, the specific duties fulfilled by them. Insufficient workload together with overwork can generate professional discontentment [13].

All the IAg must annually report the number and workload of professionals working at the PNAE [7]. Thus, the Fundo Nacional de Desenvolvimento da Educação (FNDE, National Fund for the Development of Education) monitors the teams that work for the program. However, the IAg receive no feedback or are requested to comply with Federal Board of Dietitians Resolution [9]. Actions in this sense could help increase the hiring of professionals to meet the demands of the IAg.

The Federal Board of Dietitians Resolution [9] also establishes the obligatory duties that the professional must develop at the PNAE, such as nutritional status evaluation, identification of individuals with special nutritional needs, menu development, activities related to $\mathrm{FNE}$, among others. Bureaucratic activities of the PNAE, such as management, procurement, accounting and cash basis accounting, are performed by all interviewees. Although these are not technical assignments, the bureaucratic activities are performed in part or fully by the dietitian since non-compliance can affect the receiving of financial resources from the FNDE.

Studies suggest that the difficulties encountered by dietitians concerning the management of people and of the PNAE are due to poor professional training as undergraduate courses do not provide these practical experiences $[13,14]$. However, it is believed that, although dietitians have knowledge, the excess of duties and limited number of professionals makes it difficult the perform all these tasks.

It was found during the research that half of the dietitians perform or assist the training of family farmers. The interaction of dietitians with family farmers and participation in procurement and direct purchasing from family farming were duties incorporated into the Federal Board of Dietitians Resolution [9] when at least 30\% of the government's resources to purchase food from the family farming [3] became mandatory.

Family farmers seek help from the dietitian to assist them since they have many difficulties understandingtheprocessofpublicannouncements. Participating in public announcements is simpler than public procurements, however, it can still be complex and bureaucratic for family farmers [2123]. Tasks such as using a software to prepare sales project, for example, can be difficult to perform. In addition, the dietitian needs to guide the farmers regarding the quality and sanity of produce. According to the interviewees, training is still insufficient to meet the needs of the PNAE. In addition interacting with family farmers, other demands were incorporated into the legislation [3], such as the inclusion of fruit and vegetables, ban on low-nutritional beverages, and restriction of sugar, sodium, and saturated fat. These demands require more work when planning the 
menus. These requirements also stimulate the acquisition of fresh food (possibly from family farming) and reduction of processed foods.

The inclusion of these new duties increased the work demand of the dietitian from the PNAE due to the greater number of suppliers and the need to manage family farmers. This new approach requires professionals to understand the seasonality and the local production so that they can incorporate these products into the school menus [3,9].

All interviewed dietitians agreed that the inclusion of family farming produce, even with great effort, brought benefits to the SFP, such as improved nutritional value, respect for local eating habits, health benefits and improvement in the FNS of students, which is in agreement with other authors [22-26].

Family farmers, as well as members of the $\mathrm{SFB}$, rely on the dietitian to manage PNAE and advise them, as recommended by the Federal Board of Dietitians Resolution [9]. All interviewed dietitians perform this duty and assist organizing the SFB, leading meetings, conducting school visits, and organizing and mentoring committees for cash basis accounting.

Other activities developed by the dietitians involve the Sistema de Gestão de Conselhos (Board Management System) [8] so that the SFB can analyze the cash basis accounting online. However, many SFB do not have the necessary structure to perform the activities, such as computer equipment and a secretary. Similar to other boards, the SFB counts on the voluntary and unpaid participation of people from the school community, and participation does not always work actively as required by the legislations $[24,27]$. The municipalities studied are small and medium size and often do not have enough financial support to hire human resources to advise the SFB. The dietitians, as program managers, perform these duties, which may hinder their technical duties.
The School Feeding Board develops relevant work in social control, but it is a challenge for the PNAE to ensure that the board effectively and independently supervises the program [23]. When work of the SFB is engaged and effective, it can influence public management and the hiring of professionals [24-28].

In addition to the aforementioned activities, dietitians must perform activities for FNE and FNS to promote healthy eating habits, fight child obesity, prevent chronic non-communicable diseases, and improve the health of schoolchildren [8]. Actions aimed at the development of healthy eating habits and health promotion, as stated in the Federal Board of Dietitians Resolution [9], are carried out less frequently by the interviewed dietitians, as they require assistance and engagement from other people, mainly for nutritional evaluation, FNE and acceptability tests.

Mello et al. [12] agree that these activities are complex and require planning, availability of materials and support from third parties, resulting in extra workload to be performed. Consequently, other more urgent activities directly connected to the SFP may interfere. For this reason, the dietitians interviewed use matrix models [29] to perform these tasks, when a leader counts on the support of a group to pass on information or develop tasks to reach a common goal. Dietitians provide instruction on food and nutrition to subjects in the school community, such as to cooks, teachers, pedagogues and principals, usually during pedagogical meetings, to assist them in developing FNE-related projects. However, this strategy should be seen as outreach actions and not as a replacement of the dietitian [7].

According to the interviewees, with the excessive work demand and insufficient working hours, activities such as preparation of standardized recipe files, preparation and implementation of a manual of good practices, preparation of annual work plan, and application of acceptability tests are not prioritized. These 
activities are considered important by dietitians, but these are also pointed out as the most difficult to perform [14].

When dietitians were asked about the activities not foreseen in their duties, they reported that they felt the need to be seen as technical professionals and demand better working conditions. However, they experience the everyday difficulties faced by the IAg to offer quality food to schoolchildren and, therefore, they end up performing these activities. It is noted that dietitians are important players so that the current legal milestones are executed and reach their objectives. However, some authors report the difficulties of dietitians in exercising all of their duties at the PNAE $[7,14]$ due to work overload, since there are few professionals to perform all the activities, as observed in the present study.

Generally, the dietitian is hired by the IAg to act as manager of the program due to the obligation of the PNAE and as a condition to receive financial resources. Considering that funding is a priority for the IAg, it would be interesting for the FNDE to help municipalities meet the number of dietitians per schoolchild.

Nogueira et al. [30] analyzed the PNAE from four basic structures that support it as a public policy. The formal structure is composed of a program legislation; the substantive refers to the people involved (such as the dietitian); the material involves the funding of the Program by the government; and the symbolic is composed of the knowledge, values, interests and rules that legitimize the policy. In this sense, the duties of the dietitians require the combination of these four structures. In order to be able to fulfill all the necessary activities, legislation must be consistent, observed by both the social actors and the State, and in agreement with the symbolic structure that involves the eating and feeding at schools.

One limitation of the present study was the lack of information about the purpose of the dietitians regarding the area of professional activity since, in view of the problems they face, they were not asked if they wished to change the field of professional activity. Yet, since none of the included municipalities had the adequate number of dietitians, the present study only pointed out the difficulties of not complying with the legislation without pointing out the differences if the minimum number of professionals were met. The strong point of the study was the quantitative evaluation of the presence of the dietitian at the PNAE. Moreover, the study raises relevant questions about PNAE management, such as the difficulties encountered to carry out the activities and the need for technicians to assist the dietitian in administrative and bureaucratic activities to optimize the execution of their private affairs.

\section{CONCLUSION}

The number of dietitians and their workload do not meet the legal parameters for the number of students at the IAg studied, although all of them have responsible dietitians for the PNAE. Almost one-third of IAg do not comply with current regulations regarding the professional's minimum workload of 30 hours per week. Insufficient workload and excessive demand for PNAE-related activities may prevent dietitians from developing important technical activities that are exclusive to their daily professional work.

Therefore, the incorporation of new duties for the dietitian of the SFP should be carefully assessed, since the number of professionals in the PNAE has been insufficient. Adequate working conditions, number of professionals and satisfactory workload must be met for the development of activities as established by law. The hiring of nutrition and dietetic technicians and administrative assistants to carry out bureaucratic tasks should be encouraged, as bureaucratic matters are essential for the effective functioning of the program and could be carried out by other professionals. Thus, it is 
believed that the dietitian can develop activities related to nutritional assessment, monitoring and FNE to improve nutrition and quality of life of the beneficiaries.

To further research in this field, studies should conducted in municipalities that meet the adequate number of professionals for the PNAE to observe the reality of these locations and, possibly, they could serve as models for the implementation of the program.

\section{CONTRIBUITION}

PFF PIRES, MR BEUX and SMR FERREIRA participated in all stages of the research, from the conception, design of the study to the final writing of the submitted version of the manuscript. A RETONDARIO participated in the interpretation of the results and writing of the manuscript, with a critical revision of the intellectual content. CCB ALMEIDA and ST SCHMIDT participated in the writing and final approval of the submitted version of the manuscript. All authors have approved the final version of the manuscript, and state that they are responsible for all aspects of the study, ensuring its accuracy, integrity, and stating no conflict of interest.

\section{RE FER E N CES}

1. Organização das Nações Unidas. Com 47 milhões de crianças alcançadas, Brasil é referência global em refeições escolares. Brasília: ONU; 2013 [acesso 2017 fev 19]. Disponível em: https://goo. gl/opshaQ

2. Ministério da Educação (Brasil). Fundo Nacional de Desenvolvimento da Educação. Sobre o PNAE. Brasília: Ministério da Educação; 2016 [acesso 2016 jun 24]. Disponível em: http://goo.gl/K0T87v

3. Fundo Nacional de Desenvolvimento da Educação. Lei $n^{\circ} 11.947$, de 16 de julho de 2009. Dispõe sobre o atendimento da alimentação escolar e do Programa Dinheiro Direto na Escola aos alunos da educação básica. Diário Oficial da União. 2009; 16 jul.

4. República Federativa do Brasil. Lei n 8.913, de 12 de julho de 1994. Dispõe sobre a municipalização da merenda escolar. Diário Oficial da União. 1994; 12 jul.
5. Fundo Nacional de Desenvolvimento da Educação. Resolução $n^{\circ} 32$, de 10 de agosto de 2006. Estabelece as normas para a execução do Programa Nacional de Alimentação Escolar. Diário Oficial da União. 2006; 10 ago.

6. Vasconcelos FAG, Calado CLA. Profissão nutricionista: 70 anos de história no Brasil. Rev Nutr. 2011;24(Supl.4):605-17. https://doi.org/10.1590/ S1415-52732011000400009

7. Chaves LG, Santana TCM, Gabriel CG, Vasconcelos FAG. Reflexões sobre a atuação do nutricionista no Programa Nacional de Alimentação Escolar no Brasil. Ciênc Saúde Coletiva. 2013;18(4):917-26. https://doi.org/10.1590/S1413-81232013000 400003

8. Brasil. Resolução/CD/FNDE n 26 , de 17 de junho de 2013. Dispõe sobre o atendimento da alimentação escolar aos alunos da educação básica no âmbito do Programa Nacional de Alimentação Escolar (PNAE). Diário Oficial da União. 2013; 17 jun.

9. Conselho Federal de Nutricionistas. Resolução $n^{\circ} 465$, de 23 de agosto de 2010. Dispõe sobre as atribuições do Nutricionista, estabelece parâmetros numéricos mínimos de referência no âmbito do Programa de Alimentação Escolar (PAE) e dá outras providências. Diário Oficial da União. 2010; 16 jun.

10. Senado Federal (Brasil). Constituição (1988). Constituição da República Federativa do Brasil. Art. 5, inciso II. Brasília: Senado Federal: Centro Gráfico; 1988.

11. Peixinho A, Balaban D, Rimkus L, Schwartzman $F$, Galante AP. Alimentação escolar no Brasil e nos Estados Unidos. Mundo Saúde. 2011 [acesso 2017 fev 20];35(2):128-36. Disponível em: http://www. saocamilo-sp.br/pdf/mundo_saude/84/128-136. pdf

12. Mello AL, Vidal JPO, Sampaio LR, Santos LAS, Freitas MCS, Fontes GAV. Perfil do nutricionista do programa nacional de alimentação escolar na região Nordeste do Brasil. Rev Nutr. 2012;25(Supl.1):119-32. https://doi.org/10.1590/ S1415-52732012000100011

13. Scarparo ALS, Oliveira VR, Bittencourt JMV, Ruiz ENF, Fernandes PF, Zys JZ, et al. Formação para nutricionistas que atuam no Programa Nacional de Alimentação Escolar: uma avaliação da efetividade. Ciênc Saúde Coletiva. 2013;18(4):1001-8. https:// doi.org/10.1590/S1413-81232013000400013

14. Honório ARF, Batista SH. Percepções e demandas de nutricionistas da alimentação escolar sobre sua formação. Trab Educ Saúde. 2015;13(2):473-92. https://doi.org/10.1590/1981-7746-sip00013

15. Yin RK. Estudo de caso: planejamento e métodos. $4^{\mathrm{a}}$ ed. Porto Alegre: Bookman; 2010. 
16. Instituto Paranaense de Desenvolvimento Econômico e Social. Diagnóstico socioeconômico do território Vale do Ivaí. $1^{\text {a }}$ fase: caracterização global. Curitiba: Instituto Paranaense de Desenvolvimento Econômico e Social; 2007 [acesso 2014 jan 28]. Disponível em: https://goo.gl/fJ7NT3

17. Instituto Brasileiro de Geografia e Estatística. Cidades 2017. Brasília: IBGE; 2017 [acesso 2017 fev 19]. Disponível em: https://goo.gl/HOR4eD

18. Instituto Paranaense de Desenvolvimento Econômico e Social. Índice de Desenvolvimento Humano Municipal segundo os municípios do Paraná: 1991/2000/2010; e Índice de Desenvolvimento Humano Municipal segundo as Unidades da Federação - Brasil - 1991/2000/2010. Curitiba: IPARDES; 2013 [acesso 2017 fev 23]. Disponível em: https://goo.gl/SgrxQ5

19. Instituto Nacional de Estudos e Pesquisas Educacionais Anísio Teixeira. Censo Escolar 2013 - anexo | e anexo ||. Brasília: INEP; 2014 [acesso 2014 mar 13]. Disponível em: http://portal.inep.gov.br/ basica-censo

20. Ferreira V. Artes e manhas da entrevista compreensiva. Saúde Soc. 2014;23(3):979-92. https:// doi.org/10.1590/S0104-12902014000300020

21. Becker C, Andersson FS, Altemburg SGN, Costa LC. Novas concertações sociais e antigos entraves "burocráticos": a produção de base familiar e ecológica frente aos desafios de acesso ao PNAE. Cad Agroecol. 2011 [acesso 2014 jul 22];6(2). Disponível em: http://www.aba-agroecologia.org. br/revistas/index.php/cad/article/view/10766

22. Triches RM, Schneider S. Desestruturar para construir: interfaces para a agricultura familiar acessar o programa de alimentação escolar. Est Soc Agricult. 2012 [acesso 2015 nov 24];20(1):66-105. Disponível em: http://r1.ufrrj.br/esa/N2/ojs/index. php/esa/article/view/349

23. Triches RM, Schneider S. Alimentação Escolar e Agricultura Familiar: reconectando o consumo à produção. Rev Saúde Soc. 2010 [acesso 2014 jun 18];19(4):933-45. Disponível em: http://www. revistas.usp.br/sausoc/article/view/29715/31590
24. Bezerra OMPA, Bonomo E, Silva CAM, Correa MS, Souza AA, Santos PCT, et al. Promoção da aquisição de produtos da agricultura familiar para a alimentação escolar em Territórios da Cidadania de Minas Gerais e Espírito Santo. Rev Nutr. 2013;26(3):335-42. https://doi.org/10.1590/S141 5-52732013000300008

25. Saraiva EB, Silva APF, Sousa AA, Cerqueira GF, Chagas CMS, Toral N. Panorama da compra de alimentos da agricultura familiar para o Programa Nacional de Alimentação Escolar. Ciênc Saúde Coletiva. 2013;18(4):927-36. https://doi.org/10. 1590/S1413-81232013000400004

26. Santos AM, Mitja D. Agricultura familiar e desenvolvimento local: os desafios para a sustentabilidade econômico-ecológica na comunidade de Palmares II, Parauapebas, PA. Rev Interações. 2012;13(1):39-48. https://doi.org/10.1590/\$1518-7 0122012000100004

27. Belik W, Chaim NA. O programa nacional de alimentação escolarea gestão municipal: eficiência, administrativa, controle social e desenvolvimento local. Rev Nutr. 2009;22(5):595-607. https://doi. org/10.1590/S1415-52732009000500001

28. Gabriel CG, Machado MS, Schmitz BAS, Corso ACT, Caldeiras GV, Vasconcelos FAG. Conselhos municipais de alimentação escolar em Santa Catarina: caracterização e perfil de atuação. Ciênc Saúde Coletiva. 2013;18(4):971-8. https://doi.org/10. 1590/S1413-81232013000400009

29. Domene SMA. A escola como ambiente de promoção da saúde e educação nutricional. Psicol USP. 2008;19(Supl.4):505-17. https://doi.org/10.15 90/S0103-65642008000400009

30. Nogueira RM, Barone B, Barros TT, Guimarães KRLSLQ, Rodrigues NSS, Behrens JH. Sixty years of the National Food Program in Brazil. Rev Nutr. 2016:29(2):253-67. https://doi.org/10.15 90/1678-98652016000200009

Received: August 26, 2016

Final version: February 24, 2017 Approved: April 3, 2017 